\title{
MATERNAL IMMUNOGLOBULIN IN THE SERUM OF NEWBORN LAMBS AND ITS RELATION WITH NEONATAL MORTALITY
}

\author{
Chekol DEMIS ${ }^{\star m}$, Derib AYDEFRUHIM, Yeshitila WONDIFRA, Firdawok AYELE, Enyiew ALEMNEW and Tadiwos ASFAW \\ Debre Birhan Agricultural Research Center, P.O.Box 112, Debre-Birhan, Ethiopia \\ Email: chekgetdvm07@gmail.com \\ Supporting Information
}

ABSTRACT: The study was conducted on 153 neonatal lambs of one of the highland breeds of sheep, locally called "Menz sheep" in North-Eastern part of Ethiopia, with the aim of assessing the relationship of total serum immunoglobulin level and neonatal lamb mortality in the first one month of life. The overall mortality in neonates was $8.5 \%$. Surviving lambs $(2.43 \pm 0.35 \mathrm{~kg})$ were significantly heavier than those that died during the neonatal period $(2.21 \pm 0.55 \mathrm{~kg})$. Males $(2.45 \pm 0.31 \mathrm{~kg})$ were significantly heavier than females $(2.37 \pm 0.43 \mathrm{~kg})$. The lambs that survived the neonatal period had a significantly higher level of immunoglobulin (31.71 \pm 12.88 Zinc Sulphate Turbidity units) than those that died (12.77 \pm 5.25 Zinc Sulphate Turbidity units). Neonatal lambs with total serum immunoglobulin levels below 12 Zinc Sulphate Turbidity units may be considered as an indication of failure of passive transfer of colostrum immunoglobulins and consequently increased the susceptibility of lambs to diseases and subsequent deaths. The neonatal lambs with lower average birth weight $(2.21 \mathrm{~kg})$ and lower average total serum immunoglobulin level (12.77 Zinc Sulphate Turbidity units) had found dead before the first 30 days of their age. Most deaths of lambs occur in the first few days of birth that are typically associated with lower birth weight which also led to weakness, taking longer time to stand up and reduced chance of survival than lambs of heavier weight. Hence, several works have to be done to further improving the birth weight of newborn lambs as well as the nutritional status of the dam so that lambs may receive sufficient and good quality amount of colostrum from the first few hours of birth.

Keywords: Colostrum, Immunoglobulins, Neonatal lamb, Mortality.

\section{INTRODUCTION}

Neonatal lambs are extremely vulnerable to infectious diseases as they are born immunologically nave. A major factor affecting neonatal sensibility to pathogens is the permeable immature gut. This permeability of the gut allows the initial immunoglobulin passage, but increases also the risk for pathogens to enter (Fischer et al., 2019). However, colostrum ingestion itself accelerates the process of intestinal closure; thereby it is also preventing the route of neonatal infection (Dwyer, 2008).

The maternal immunoglobulins acquired through the colostrum play a pivotal role in the defense mechanism of lambs against neonatal diseases until their own immune system is primed and produces a protective amount of antibodies. Immunoglobulins are not detected in the serum of lambs before the first intake of colostrum (Klobasa and Werhahn, 1989). The absorption of immunoglobulins from the intestine is maximum during first six hours of life and no absorption occurs 24-36 hours postpartum. Hence, the peak Ig levels are obtained in the serum of neonatal ruminants around these times in the immediate postpartum period (Tizard, 1992). Ideally, the maternal immunity should be transferred in utero to their fetuses so that they are brought into the world protected against the microorganisms (Fisher, 1980; Godden et al., 2019). However, placental barriers in ruminants do not allow the passage of immunoglobulins from dams to neonates, and therefore the lamb has to be dependent entirely on antibodies received via colostrum (Tizard, 1992). Colostrum is not only rich in immunoglobulins as compared to milk but is also an excellent source of energy, vitamin A and essential minerals (Khan and Khan, 1996).

Globulin proteins are serum proteins that are classified into three groups in ruminants; $\alpha$-, $\beta$-, and $\gamma$ - globulins (Tizard, 1987). The $\mathrm{y}$-globulin fraction contains mainly immunoglobulins, which are proteins with antibody activity (Tizard, 1987). According to Tizard (1987), sheep have four different types of immunoglobulins; IgG, IgA, IgM and IgE and IgG is the immunoglobulin found in highest concentration in serum. Sheep have an epitheliochorial placenta, the immunoglobulins do not cross the placental barrier and the lamb is born without any circulating antibodies. The passive immune transfer from the ewes' colostrum to the lamb is of utmost importance for the survival of the offspring, providing it with some resistance against infectious diseases (Nowak and Poindron, 2006). Immunoglobulin-synthesis is initiated at approximately 3 weeks of age in neonatal lambs (Klobasa et al., 1985). 
Intestinal closure happens approximately 24 hours after birth, meaning that the passive absorption of immunoglobulins in the intestine seize. When suckling begins; the level of immunoglobulins in the blood starts to rise rapidly during the first hour and reaches a peak around 24 hours after parturition (Nowak and Poindron, 2006). Shubber et al, (1979), concluded that larger volumes of colostrum correlate with larger amounts of immunoglobulins. Adequate passive immune transfer (PIT) has been determined in some studies to be reached when the lambs IgG intake was above $30 \mathrm{~g}$ during the first $24 \mathrm{~h}$ of life (Alves et al., 2015). Consequently some studies suggest that the failure of passive immune transfer (FPIT) for the neonatal lamb has a significant effect on neonatal mortality and losses because of infectious causes correlate positively with low concentrations of serum immunoglobulins (Ahmad et al., 2000). The intestine is unselectively permeable, therefore, all immunoglobulins types can be absorbed (Sawyer et al., 1977). The permeability remains highest immediately after birth to 6 hours of life. Then immature fetal type of cells capable of transfer of intact immunoglobulins is gradually replaced by a digestive type of cells (Tizard, 1992). Smeaton and SimpsonMorgan (1985) also observed that the layer of cells responsible for absorption of colostral antibodies progressively disappears from the villi, resulting in closure which usually completes 24-36 hours after birth (Khan and Khan, 1991 b). So, lambs absorb intact immunoglobulins from ingested colostrum only during the first day of life (Klobasa et al., 1986). Immunoglobulins reach peak level on day I of lamb life, then decline during the next 3 weeks (Smith et al., 1976).

According to Bekele et al. (1992), failure and partial failure of Ig transfer from dam to lambs are observed in 1.8 and $\mathbf{1 5 . 3}$ per cent lambs, respectively. Passive transfer failure was observed in 14 per cent of apparently healthy lambs and in 46 per cent of lambs dying of natural causes between 24 hours and 5 weeks of age (Sawyer et al., 1977). The results of Logan and Irwin (1977) showed that about 20.2 \% of lambs born were hypogammaglobulinaemic and were more susceptible to neonatal diseases. Findlay (1973) also observed that all lambs with immunoglobulins less than 20 ZST units die during first week of life, mortality in lambs with 20-40 ZST units was very low and no mortality in lambs with 50 ZST units.

Failure of passive transfer of immunoglobulins to neonatal lambs has a significant effect on neonatal mortality, and losses due to infectious causes are positively correlated with low concentrations of serum immunoglobulins (Sallam, 2019; Ibrahim et al., 2020). According to Hodgson et al. (1992), morbidity and mortality rates are higher in colostrumdeprived lambs (80 and $67 \%$ ) than colostrum fed lambs (20 and $13 \%$ ) and $20 \%$ of colostrum-deprived lambs die within the first week of life. The concentration of these maternal immunoglobulins in the circulation at 24 hours after birth can be used as an indication of sufficient immunity for the survival of neonatal lambs or susceptibility of lambs to neonatal diseases (Reid, 1972). There are several simple tests that can be used to verify whether or not neonates have received adequate colostrum. The most popular test is the zinc sulphate turbidity test (Roy, 1990). This test has been used by different authors in different species of animals and has been found to be in good agreement with immunoglobulins values determined by other laboratory techniques and it is also simple to use in the laboratory (Ahmad et al., 2000). Hence, the objective of this study is to measure the influence of failure of maternal immunoglobulin transfer on mortality of lambs in the first 30 days of life.

\section{MATERIALS AND METHODS}

\section{Study area}

The study was conducted in Debre Birhan Agricultural research Center (DBARC). DBARC is found in North Shewa Administrative Zone of the Amhara National Regional State, North eastern part of Ethiopia. It is located in the central part of the Nation, at a road distance of about 120 kilometers from Addis Ababa, the capital city of the country. Geographically, the area lies between $09035^{\prime} 45^{\prime \prime}$ to $090366^{\prime} 45^{\prime \prime}$ north latitude and $39029{ }^{\prime} 40^{\prime \prime}$ to 39031 '30" east longitude with an average elevation of about $\mathbf{2 8 2 8}$ meters above sea level. It has an average annual rain fall of about $897.8 \mathrm{~mm}$ and mean annual temperature of about $19.9^{\circ} \mathrm{C}$.

\section{Study population}

The lambs which were born from indigenous breeds of sheep (locally named as Menz sheep) were included in the study. The study animals were sourced from the dams which were kept in semi-intensive management system in DBARC. These animals were provided harvested hay and commercial concentrate feed in addition to the morning and afternoon pasture grazing. Both broad and narrow-spectrum anthelmintic drugs were administered against internal parasites based on the laboratory findings and the sheep were also vaccinated against major infectious diseases which include pasteurellosis, sheep and goat pox and peste des petits ruminants (PPR).

\section{Study design and sampling method}

An observational longitudinal study design study was conducted from August 2019 to October 2019 to evaluate the impact of level of maternal immunoglobulin transfer on mortality of neonatal lambs in the first 28 days of life. For this study, all the 153 lambs that were born during the activity season were included. Blood samples without anticoagulant were collected from the jugular vein of these new born lambs at the age of 24-48 hours post partem. Serum was separated and stored at $-20{ }^{\circ} \mathrm{C}$ for further processing and birth weight of lambs was recorded. The health of all lambs under study was monitored daily during the neonatal period. All the lambs that were included in the study were followed up starting from the date of sampling up to the first $\mathbf{2 8}$ days of age. By this, the lambs that died were recorded and their 
level of serum immunoglobulin was measured using zinc sulphate turbidity (ZST) test based on the principle of McEwan et al. (1970).

\section{Zinc sulphate turbidity test (ZST)}

The principle of the test is that Zinc sulphate at a specific concentration precipitated the gamma globulin. This creates turbidity which is proportional to the quantity of gamma globulin in the sample and can be quantified in a calorimeter at $525 \mathrm{~nm} /$ Spectrophotometer $460 \mathrm{~nm}$.

\section{Test procedure}

About $250 \mathrm{mg} \mathrm{ZnSO} \cdot \cdot 7 \mathrm{H}_{2} \mathrm{O}$ was diluted in $1 \mathrm{~L}$ freshly boiled water (to remove $\mathrm{CO}_{2}$ ) and 6-mL of the zinc sulphate solution was placed into sealed $7-10 \mathrm{~mL}$ plain blood collection tubes. Then, $0.1 \mathrm{~mL}$ serum was added to it and each tube was shaken by repeated inversion of the tube. After that, the mixture was kept for 1 hour at room temperature for the turbidity to develop. Finally, the turbidity developed in each tube was read in a spectrophotometer at a wavelength of 460 $\mathrm{nm}$ and the absorbance (optical density) of the turbid solution was determined and compared with control and percent turbidity calculated. Before taking the reading, null adjustment was made against the zinc sulphate solution and all the tubes were shaken further to make a uniform turbid solution.

Data analysis

All the data that were collected based on the above procedures were analyzed using multivariate analysis method of the General Linear Model in SPSS version 20.

\section{RESULTS}

The study considered 153 neonatal lambs and assessed for the level of serum immunoglobulins with in the first 48 hours of age after birth. 13 out of 153 lambs were died before 30 days of age with overall neonatal mortality of $8.5 \%$. The mortality rates in male and female neonatal lambs were found $10.3(8 / 78)$ and $6.7 \%(5 / 75)$, respectively.

\section{Serum immunoglobulins levels}

The mean serum immunoglobulins level recorded was $30.10 \pm 13.49$ ZST units. The average serum immunoglobulins level of surviving lambs was found $31.71 \pm 12.88 \mathrm{ZST}$ units while, the average serum immunoglobulins level of lambs that had died was found $12.77 \pm 5.25$ ZST units) (Table 1).

\section{Birth weight}

The mean birth weight was $2.41 \pm 0.37 \mathrm{~kg}$ with a range of 1.2 to $3.6 \mathrm{~kg}$. The males $(2.45 \pm 0.31 \mathrm{~kg})$ were found heavier than the females $(2.37 \pm 0.43 \mathrm{~kg})$. The surviving lambs $(2.43 \pm 0.35 \mathrm{~kg})$ were also heavier than those that died during the neonatal period $(2.21 \pm 0.55 \mathrm{~kg})$ (Table 2$)$.

\begin{tabular}{|c|c|c|c|c|}
\hline Parameter & Sex & Survival Status & Mean \pm Standard deviation & $\mathbf{N}$ \\
\hline \multirow{9}{*}{ Immunoglobulins (ZST units) } & \multirow{3}{*}{$\mathbf{F}$} & Died & $11.00 \pm 6.63^{a}$ & 5 \\
\hline & & Survived & $31.17 \pm 13.85^{b}$ & 70 \\
\hline & & Total & $29.83 \pm 14.38^{a}$ & 75 \\
\hline & \multirow{3}{*}{ M } & Died & $13.88 \pm 4.29^{a}$ & 8 \\
\hline & & Survived & $32.24 \pm 11.91^{b}$ & 70 \\
\hline & & Total & $30.36 \pm 12.66^{a}$ & 78 \\
\hline & \multirow{3}{*}{ Total } & Died & $12.77 \pm 5.25^{a}$ & 13 \\
\hline & & Survived & $31.71 \pm 12.88^{b}$ & 140 \\
\hline & & Total & $30.10 \pm 13.49$ & 153 \\
\hline
\end{tabular}

\begin{tabular}{|c|c|c|c|c|}
\hline Parameter & Sex & Survival Status & Mean \pm Standard deviation & $\mathbf{N}$ \\
\hline \multirow{9}{*}{ Birth Weight (kg) } & \multirow{3}{*}{$\mathbf{F}$} & Died & $2.03 \pm 0.53^{a}$ & 5 \\
\hline & & Survived & $2.40 \pm 0.41^{b}$ & 70 \\
\hline & & Total & $2.37 \pm 0.43$ & 75 \\
\hline & \multirow{3}{*}{$\mathbf{M}$} & Died & $2.32 \pm 0.57^{a}$ & 8 \\
\hline & & Survived & $2.46 \pm 0.27^{b}$ & 70 \\
\hline & & Total & $2.45 \pm 0.31$ & 78 \\
\hline & \multirow{3}{*}{ Total } & Died & $2.21 \pm 0.55^{a}$ & 13 \\
\hline & & Survived & $2.43 \pm 0.35^{b}$ & 140 \\
\hline & & Total & $2.41 \pm 0.37$ & 153 \\
\hline
\end{tabular}




\section{DISCUSSION}

From 153 lambs studied, 13 of them died before 30 days of age with overall neonatal mortality of about $8.5 \%$. According to this study, the mortality rates in male and female neonatal lambs were found $10.3(8 / 78)$ and $6.7 \%(5 / 70)$, respectively. However, there was no significant difference $(P>0.05)$ between immunoglobulins levels of both sexes. Similarly, Cinpercescu (1977) and Esser et al. (1989) also reported no difference in male or female immunoglobulins levels.

\section{Serum immunoglobulins levels}

The present study finding, indicates the average serum immunoglobulins level of surviving lambs (31.71 12.88 ZST units) were significantly $(P<0.05)$ higher than those that died during the neonatal period $(12.77 \pm 5.25$ ZST units. The mean serum immunoglobulins level recorded in thisstudy was almost similar to the findings of Reid (1972) and AL salami and Sinclair (1977), who reported serum immunoglobulin levels of about 27.40 \pm 1.70 and 30.90 ZST units, respectively. In the present study, the majority of lambs had ZST values between 20 and 40 units which are in accordance with findings recorded by Reid (1972) and Logan and Irwin (1977) in lambs. Based on this study, thirteen lambs out of 153 (8.5\%) were found markedly deficient in serum immunoglobulin level (<13 ZST units), and which died later.

The importance of colostrum in reducing the incidence of neonatal lamb mortality is obvious by the fact that the nine out of thirteen lambs that died in the present study had an immunoglobulin level below 10 ZST units. Such lambs would be at high risk of susceptibility to diseases, and subsequent death as the observations reported by Reid (1972), Findlay (1973) and Logan and Irwin (1977). But according to Villar and Vulich (1980), ZST units in the range of 0-20 are indications of high risk of subsequent death. According to the present study, most of the mortalities were recorded during the first week of life. The finding is in agreement with Jordan and Le-Feuvre (1989), Otesile and Oduyo (1991) and Fentie et al. (2020) who reported maximum morbidity/mortality of lambs during the first week of life.

The lambs that survived the neonatal period had a significantly $(P<0.05)$ higher level of immunoglobulins than those that died (Table 1). The result is similar with the findings recorded by Sawyer et al. (1977), Villar and Vulich (1980), Otesile (1994), and Kenyon et al. (2019). However, Bekele et al. (1992) reported no significant differences between mortality during the neonatal period and immunoglobulins concentration. The newborn leaves the sterile uterus to an environment containing many pathogens. The neonates are often overcome by infectious diseases, even by agents that are relatively nonpathogenic to adult animals (Banks, 1982). In the absence of specific immunity at birth due to of placental barriers (Tizard, 1992), ruminant neonates have to rely on antibodies received via colostrum (Khan and Khan, 1991). These antibodies play a significant role in the defense mechanism of newborn lambs until their own immune systems are primed and produce a protective level of antibodies (Tizard, 1992).

In the present study, six lambs out of thirteen (46.15\%) showed sign of diarrhea, before death; while four (30.77\%) died after signs of a respiratory disorder and the rest three died with no specific clinical signs. According Fisher (1980), IgM was the class of immunoglobulin found to be deficient in neonates that died of septicemic and bacteremic causes, whereas IgG was found to be deficient in neonates that died of diarrhea. IgA seems to be re-excreted and somehow halts the diarrheic process. According to Smith et al. (1976), a small amount of colostrum IgG, after being absorbed, is secreted in the nasal and lachrymal secretions of lambs and this plays a valuable role in preventing respiratory infections before local production of IgA and IgM at the age of 2-3 weeks.

\section{Birth weight}

The survival of neonatal lambs was also observed with respect to their birth weight. The mean birth weight was found $2.41 \pm 0.37 \mathrm{~kg}$ and the males $(2.45 \pm 0.31 \mathrm{~kg})$ were found heavier than females flock members $(2.37 \pm 0.43 \mathrm{~kg})$. The surviving lambs $(2.43 \pm 0.35 \mathrm{~kg})$ were also heavier than those that died during the neonatal period $(2.21 \pm 0.55 \mathrm{~kg})$. Being physically weak, the lambs with low birth mass were unable to suckle sufficient amount of colostrum, and as a result, the immunoglobulins level in their serum was low. The physical weakness and low immunoglobulins led to increased mortality in lambs with a low birth mass. The finding of the study is similar with the works which were reported by Purser and Young (1983), Ducrot et al. (1989), Tadich et al. (1990) and Otesile and Oduye (1991). All lambs with higher birth weight survived the neonatal period. However, according to Poonia et al. (1983), as birth mass increases above $3.0 \mathrm{~kg}$, the mortality also increases. Contrary to this finding, Dalton et al. (1980) reported that a lamb with a birth mass of from 3.5 to $5.5 \mathrm{~kg}$ had the lowest mortality. According to Hindson and Winter (2002), neonatal lambs with low birth weight often have poor suckling drive or they are unable to compete with stronger lambs for available milk. Hence, they are disadvantaged both from total milk intake and reduced immunoglobulin intake.

\section{CONCLUSION}

Based on the finding of the present study, it can be concluded that the total serum immunoglobulin levels in neonatal lambs within the first one to two days of age, had a good indication for the extent of the absorption of colostral antibodies from the dam. The neonatal lambs with lower average birth weight $(2.21 \mathrm{~kg})$ and lower average total serum immunoglobulin level (12.77 ZST units) had found dead before the first $\mathbf{3 0}$ days of their age. Hence, several works have to be done to further improve the birth weight of newborn lambs as well as the nutritional status of the dam so that lambs can suckle starting from the first few hours of birth and receive sufficient amount good quality colostrum. 


\section{DECLARATIONS}

\section{Corresponding author}

E-mail: chekgetdvm07@gmail.com

\section{Authors' contributions}

Chekol D contributed to the research design, analysis, interpretation of the data and writing the manuscript. Derib $A$, Yeshitila W, Firdawok A, Enyiew A and Tadiwos A contributed to the blood sample collection and laboratory work.

\section{Acknowledgement}

The research team would like to thank Debre Birhan Agricultural Research Center of Amhara Agricultural Research Institute, Ethiopia for its permission to use the new born lambs for this purpose and as well as the laboratory facilities. We are also thankful for individuals with direct and indirect contribution for this work.

\section{Conflict of interest}

None of the authors have conflict of interest.

\section{REFERENCES}

Ahmad R, Khan A, Javed M T and Hussain I (2000). The level of immunoglobulins in relation to neonatal lamb mortality in Pak-Karakul sheep. Veterinarski Arhiv, 70 (3): 129- 139. https://hrcak.srce.hr/96739

Alves AC, Alves NG, Ascari FB, Jungueira FB, Coutinho A S, Lima RR, Pérez JR, De Paula So, Furusho-Garcia IF and Abreu LR (2015). Colostrum composition of Santa Ines sheep and passive transfer of immunity to lambs. Journal of Dairy Science, 98 (6): $3706-3716$. DOI: https://doi.org/10.3168/jds.2014-7992

Banks KL (1982). Host defense in the newborn animal. Journal of the American Veterinary Medical Association, 181: 1053-1056. PMID: 6757211, AGRIS

Bekele T, Otesile EB, and Kasali OB (1992). Influence of passively acquired colostral immunity on neonatal lamb mortality in Ethiopian highland sheep. Small Ruminant Research, 9: 209-215. https://doi.org/10.1016/0921-4488(92)90151-S

Cinpercescu DD (1977). Dynamics of serum immunoglobulin concentration in sheep during pregnancy and lactation. Research in Veterinary Sciences, 22: 23-27. https://doi.org/10.1016/S0034-5288(18)33306-X

Dalton DC, Knight TW, and Johnson DL (1980). Lamb survival in sheep breeds on New Zealand hill country. New Zealand Journal of Agricultural Research, 23: 167-173. https://doi.org/10.1080/00288233.1980.10430783 I Google Scholar

Ducrot C, Arnould B, Berthelon C and Calavas D (1989). Establishment of risk factor in perinatal mortality of lambs in a survey of 92 sheep flock in southeaster France. Epidemiologie et sante Animale, 16: 57-75.

Dwyer CM (2008). The welfare of the neonatal lamb. Small Ruminant Research, 76: 31- 41. https://doi.org/10.1016/i.smallrumres.2007.12.011

Esser D, Schmit FW, Von Korn S and Peters KJ (1989). Immunoglobulins G status of ewes and their lambs. Journal of Animal Breeding and Genetics, 106: 120-128. AGRIS I Google Scholar

Fentie T, Guta S, Mekonen G, Temesgen W, Melaku A, Asefa G, Tesfaye S, Niguse A, Abera B, Kflewahd, et al. (2020). Assessment of Major Causes of Calf Mortality in Urban and Periurban Dairy Production System of Ethiopia. Veterinary Medicine International, 2020: Article ID: 3075429. https://doi.org/10.1155/2020/3075429

Findlay C R (1973). Serum immune globulin levels in lambs under a week old. Veterinary Record, 92 : 530-532. http://dx.doi.org/10.1136/vr.92.20.530, Google Scholar

Fischer, A. J., Villot, C., van Niekerk, J. K., Yohe, T. T., Renaud, D. L., \& Steele, M. A. (2019). Invited Review: Nutritional regulation of gut function in dairy calves: From colostrum to weaning. Applied Animal Science, 35(5), 498-510. https://doi.org/10.15232/aas.2019$\underline{01887}$

Fisher E W (1980). Neonatal survival. Brish Veterinary Journal, 136: 585-589. https://doi.org/10.1016/S0007-1935(17)32139-5

Godden SM, Lombard JE, and Woolums AR (2019). Colostrum Management for Dairy Calves. The Veterinary Clinics of North America. Food Animal Practice, 35(3): 535-556. https://doi.org/10.1016/j.cvfa.2019.07.005

Hindson JC and Winter AC (2002). Manual of Sheep Diseases, Blackwell Science Ltd, 2nd edition, USA. Available Link

Hodgson JC, Moon GM, Hay LA and Quirie M (1992). Effectiveness of substitute colostrum in preventing disease in newborn lambs. British Society of Animal Production Occassional Publication, 15: 163-165. DOI: https://doi.org/10.1017/S0263967X00004183

Ibrahim NH, Badawy MT, Zakzouk IA and Younis FE (2020). Kids' survivability as affected by their body weight, blood biochemical indices and maternal and kids' behavior in baladi and shami goats under semi-arid condition. World's Veterinary Journal, 10 (1): $105-117$. DOI: https://dx.doi.org/10.36380/scil.2020.wvj15

Jordan DJ and Le-Feuvre AS (1989). The extent and causes of perinatal lamb mortality in 3 flocks of merino sheep. Australian Veterinary Journal, 66: 198-201. https://doi.org/10.1111/j.1751-0813.1989.tb09807.x

Kenyon PR, Roca Fraga FJ, Blumer S and Thompson AN (2019). Triplet lambs and their dams - a review of current knowledge and management systems, New Zealand Journal of Agricultural Research, 62: 399-437. https://doi.org/10.1080/00288233.2019.1616568

Khan A and Khan MZ (1991 b). Aetiopathology of neonatal calf mortality. Medical Journal of Islamic World Academy of Sciences, 4: 159165. https://www.journalagent.com/ias/pdfs/IAS_4_2_159_165.pdf

Khan A and Khan MZ (1991a). Immunoglobulins in relation to neonatal calf mortality. Pakistan Veterinary Journal, 11 : $153-162$. http://www.pvj.com.pk/pdf-files/17_4/161-167.pdf 
Khan A and Khan MZ (1996). Neonatal calf mortality in Pakistan: III: Immunoglobulins in relation to mortality in buffalo and cow neonates. Buffalo Journal, 12: 243-252. Google Scholar

Klobasa $F$ and Werhahn E (1989). Variations in the concentrations of the immunoglobulins IgG1, IgG2, IgM and IgA in sheep. 2. Changes in the blood of lambs of different breeds and crossbreeds during the course of the rearing period. Berliner und Munchener Tierarztliche Wochenschrift. 102(10):331-7. PMID: 2719635 I Google Scholar

Klobasa F, Werhahn E and Kallweit E (1985). Pattern of immunoglobulin concentrations in lamb serum from birth through the postweaning period. A seminar in the CEC programme of coordination of agricultural research: Factors affecting the survival of newborn lambs. Brussels, 55-61.

Klobasa F, Werhahn E and Kallweit E (1986). Patterns of immunoglobulin concentrations in lamb serum from birth through the postweaning period. In: Factors affecting the survival of new born lambs. Commission of the European Communities; Luxembourg, 55-62. Google Scholar

Logan EF and Irwin D (1977). Serum immunoglobulin levels in neonatal lambs. Research in Veterinary Sciences, 23: 389-390. D0I: https://doi.org/10.1016/s0034-5288(18)33140-0, Google Scholar

McEwan AD, Fisher EW, Salman IE, Penhale WJ (1970). A turbidity test for the estimation of immune globulin levels in neonatal calf serum. Clinical Chemical Acta, 27(1): 155-163. https://doi.org/10.1016/0009-8981(70)90390-6, Google Scholar

Nowak R and Poindron P (2006). From birth to colostrum: early steps leading to lamb survival, Reproduction and Nutrition Development, 46 (4): 431-446. Doi: https://doi.org/10.1051/rnd:2006023

Otesile EB (1994). Mortality in one to six month old West African Dwarf lambs. Bulletin of Animal Health and Production (Africa), 42: 3135. Google Scholar

Otesile EB and Oduye $O 0$ (1991). Studies on factors affecting absorption of colostral immunoglobulins in newborn lambs. Bulletin of Animal Health and Production (Africa), 38: 447-452. Google Scholar

Poonia JS, Singh B and Balaine DS (1983). Studies on pre-weaning mortality in lambs of Nali and its crosses with Corriedale and Russian Merino. Livestock Adviser, 8: 7-10. Google Scholar

Purser AF and Young GB (1983). Mothering ability in two hill flocks. British Veterinary Journal, 139 (4): $296-306$. https://doi.org/10.1016/S0007-1935(17)30435-9, Google Scholar

Reid JFS (1972). Serum immune globulin concentrations of newborn Hill lambs. Veterinary Record, 90: 371-372. Google Scholar, DOI: https://doi.org/10.1136/vr.90.13.371, PMID: 5039470.

Roy JHB (1990). The calf. Volume 1. Management of health. 5th ed., pp. 258, Butterworts, London. ISBN : $040700520 X, \underline{C A B}$ Direct

Sallam AM (2019). Risk factors and genetic analysis of pre-weaning mortality in Barki lambs. Livestock Science, 230 : 103818. https://doi.org/10.1016/j.livsci.2019.103818

Sawyer M, Willadsen CH, Osburn BI and McGuire TC (1977). Passive transfer of colostral immunoglobulins from ewe to lamb and its influence on neonatal lamb mortality. Journal of the American Veterinary Medical Association. 171(12):1255-9. PMID: 604324, Google Scholar

Shubber AH, Doxey DL, Black WJ and FitzSimons J (1979). Immunoglobulin levels in ewe colostrum and in lamb serum. Research in Veterinary Science, 27 (3): 283-285. https://doi.org/10.1016/S0034-5288(18)32793-0, Google Scholar

Smeaton TC and Simpson-Morgan M W (1985). Epithelial cell renewal and antibody transfer in the intestine of the foetal and neonatal lamb. Australian Journal of Experimental Biological and Medical Sciences, 63(1): 41-51. https://doi.org/10.1038/icb.1985.5, Google Scholar

Smith WD, Wells PW and Burrells C and Dawson A MeL (1976). Maternal immunoglobulins and parainfluenza 3 virus inhibitors in nasal and lachrymal secretions and serum of newborn lambs. Clinical Experimental Immunology, 23(3): 544-553. Google Scholar, PMID: 181185

Tadich N, Cubillos V, Paredes E, Murray R and Ortiz E (1990). Neonatal lamb mortality in Valdivia Province, Chile. Archivos de Medicina Veterinaria, 22(1): 45-54. Google Scholar, CAB Direct

Tizard I (1987). Veterinary Microbiology: An Introduction. Third edition, Philadephia: Saunders Company, 401. National library of Australia, https://trove.nla.gov.au/version/22242376

Tizard I (1992). Veterinary Immunology: An introduction. $4^{\text {th }}$ Ed., W. B. Saunders Company, London, $248-257$. https://trove.nla.gov.au/version/46719374

Villar JA and Vulich SA (1980). Mortality in newborn lambs: immunoglobulin values in corriedale lambs up to one week of age. Revista de Vetrinaria Argentina, 61: 21-26. Google Scholar 